\title{
Inter-colony variation in diet and reproductive performance of great skuas Catharacta skua
}

\author{
Richard A. Phillips ${ }^{1, *}$, Paulo Catry ${ }^{1}$, David R. Thompson ${ }^{1}$, Keith C. Hamer ${ }^{2}$, \\ Robert W. Furness ${ }^{1}$
}

\begin{abstract}
'Applied Ornithology Unit, Graham Kerr Building, University of Glasgow, Glasgow G12 8QQ, United Kingdom ${ }^{2}$ Department of Biological Sciences, University of Durham, South Road, Durham DH1 3LE, United Kingdom
\end{abstract}

\begin{abstract}
Sustained population growth of great skuas Catharacta skua during the current century has been attributed largely to a high abundance of sandeels, principally Ammodytes marinus, and a plentiful supply of discards from whitefish trawlers in the vicinity of breeding colonies. A new colony of great skuas was established at St Kilda, Outer Hebrides, in 1963 and has since grown rapidly despite an apparent lack of sandeels in the waters surrounding the archipelago and the presence of only a small whitefish fishery. This paper presents an analysis of diet and breeding ecology of great skuas at Hirta, St Kilda, over 3 seasons, 1994 to 1996, with comparative data from Foula, Shetland, the largest and one of the oldest of the British colonies. At St Kilda, breeding adults, nonbreeders and chicks all fed extensively upon other seabirds ( 44 to $65 \%$ of pellets over the 3 yr), and to a lesser extent on goose barnacles Lepas sp. (18 to $30 \%$ of pellets) and fish (16 to $30 \%$ of pellets), with sandeel virtually absent from the diet 10.2 to $0.3 \%$ of pellets). In contrast, at Foula only 4 to $12 \%$ of pellets were of other seabirds, with sandeels and discarded fish together constituting the vast majority ( 4 to $36 \%$ and 55 to $88 \%$ of pellets, respectively). Despite the low availability of sandeels and discards at St Kilda, egg volumes, chick body condition and annual productivity were at least as high as at Foula, and territorial attendance of breeding adults was much higher, indicating considerably lower foraging effort during chick-rearing. Great skuas at St Kilda are therefore able to make effective use of other seabirds as a food resource during the breeding season, in sharp contrast to Foula where adult mortality increased and chick growth rates and breeding success plummeted during the marked decline in sandeel abundance in the late 1980 s.
\end{abstract}

KEY WORDS: Food supply · Predation - Foraging effort - Chick growth - Sandeel - Storm petrel

\section{INTRODUCTION}

The world population of great skuas Catharacta skua is around 13600 pairs, of which approximately $60 \%$ breed in the UK (Lloyd et al. 1991). The British population expanded rapidly (ca $7 \%$ per annum) from the turn of the century up until the late 1970s, although more recent surveys indicate a much more modest rate of increase from then until 1992 (Furness 1987, Meek et al. 1994, Sears et al. 1995). Sustained population

\footnotetext{
- Present address: Department of Biological Sciences, University of Durham. South Road, Durham DH1 3LE, UK.

E-mail:r.a.phillips@durham.ac.uk
}

growth during the 1970 s was attributed in large part to high adult survivorship and productivity due to an abundance of sandeels Ammodytes spp. in the waters surrounding breeding colonies (Furness \& Hislop 1981, Furness 1987). Discarded whitefish were also considered to be essential as a secondary food source which allowed high chick growth rates and reproductive success to be maintained even if sandeel availability declined for short periods (Furness \& Hislop 1981). When sandeel abundance in Shetland declined dramatically during the mid to late 1980s, chick growth rates and productivity on Foula plummeted, in spite of a partial switch by adults to bird meat as an alternative food source and a considerable increase in foraging effort (Hamer et al. 1991). Moreover, adult mortality 
increased during this period, resulting in a $13 \%$ decline in breeding numbers at the largest UK colony (Foula, in Shetland) between 1985/86 and 1992, apparently underlining the extent to which this species depended on sandeels during the breeding season (Klomp \& Furness 1991).

Until the late 1980 s, less than $3 \%$ of British great skuas bred outside Orkney and Shetland, although numbers were increasing in the Western Isles (Rennie 1988). Great skuas were first recorded breeding on Hirta, the main island in the St Kilda archipelago (Outer Hebrides), in 1963, and the population increased gradually at least until 1990 (Phillips et al. 1997). Since then, there has been an extremely rapid expansion to a total of 213 occupied territories in 1996 , making Hirta currently the second largest colony outside of Shetland (Phillips et al. 1997). This dramatic increase in population size has occurred despite an apparent lack of sandeels in waters immediately surrounding the archipelago (Leaper et al. 1988) and the presence of only a small whitefish fishery in the area. The situation at St Kilda therefore appears to be quite distinct from that recorded in Shetland. However, to date, no published data exist on the diet of great skuas in the Outer Hebrides or on the consequences of low sandeel and discard availability for adult foraging behaviour, chick growth or annual productivity. This paper presents an analysis of the diets and breeding ecology of great skuas at St Kilda over 3 yr from 1994 to 1996 , along with comparative data for Shetland over the same period, and discusses differences between sites in the context of interactions between great skuas and their marine food resources.

\section{MATERIALS AND METHODS}

Diets and breeding ecology of great skuas were examined on Hirta, the largest island in the St Kilda archipelago $\left(57^{\circ} 49^{\prime} \mathrm{N}, 08^{\circ} 35^{\prime} \mathrm{W}\right)$ by R.A.P., D.R.T. and K.C.H., and on Foula, Shetland $\left(60^{\circ} 08^{\prime} \mathrm{N}, 02^{\circ} 05^{\prime} \mathrm{W}\right)$ by P.C. and R.W.F. Methods followed those of Furness (1983b, 1984), Furness \& Hislop (1981) and Hamer et al. (1991).

Dietary analysis. Great skuas regurgitate the indigestible remains of food in the form of a pellet. Pellets were collected from breeding territories and club sites (areas frequented almost exclusively by nonbreeders) between late May and early August, 1994 to 1996, with the majority collected during chick-rearing. Following Furness \& Hislop (1981), fresh pellets only were collected.

In most cases, pellets contained the remains of only 1 prey type. Pellets containing bird remains were identified to lowest possible taxon, usually species, on the basis of feather type (size, colour, aroma) and the morphology of legs, feet, bill and wings where present. Both Leach's petrel Oceanodroma leucorhoa and British storm petrel Hydrobates pelagicus breed in large numbers at St Kilda, and discrimination between these 2 species was on the basis of measurements presented in Love (1976). Pellets containing great skua chick remains were excluded from analysis, as their relative incidence was not quantified in all years. Sagittal otoliths present in pellets containing fish remains were collected for later identification to species using comparative reference material and Härkönen (1986). Squid beaks were collected for later identification to lowest possible taxon using comparative reference material and Clarke (1986). Further information on diet was available from chick regurgitates collected during ringing or measuring.

The effects of colony, year and breeding status (breeding or nonbreeder) on the proportion of pellets in each prey category, and on the proportion of different species in bird pellets, were investigated using logit loglinear analysis of multidimensional contingency tables (Norusis 1988). At Foula, pellets were not collected from breeding territories in 1995, and only limited data were available on the species composition of bird pellets. These empty cells in contingency tables were treated as structural zeros. These cells do not contribute to goodness-of-fit statistics for the model and the degrees of freedom were decremented by 1 for each.

Productivity, chick growth and adult foraging effort. Eggs were measured using vernier callipers (length and breadth to the nearest $0.1 \mathrm{~mm}$ ) and total volumes (mi) calculated as $0.00048 \times$ length $(\mathrm{mm}) \times$ breadth $(\mathrm{mm})^{2}$ (Furness 1983b, 1984). Hatching success and chick survival were recorded by visiting marked nests at 3 to $4 \mathrm{~d}$ intervals throughout incubation and at approximately $10 \mathrm{~d}$ intervals during chick-rearing. Productivity data were available only for pairs that hatched 2 chicks on Foula in 1996, and so comparison between this value and that for St Kilda in the same year was restricted to pairs with 2 -chick broods. For comparative purposes, at both colonies chicks older than $30 \mathrm{~d}$ were assumed to survive to fledging. Only $3.8 \%(n=133)$ of chicks disappeared or were found dead between $30 \mathrm{~d}$ and fledging at approximately $45 \mathrm{~d}$ (R.A.P. unpubl. data).

Large samples of chicks were weighed and measured at both colonies in 1994 to 1996. Precise hatching dates were available only at St Kilda in 1996 and logistic growth curves were fitted to changes in wing length and weight with age of these chicks. Chicks from both colonies were aged from wing length by reference to the first of these curves, and an index of the body condition of chicks during the linear phase of growth, 
Table 1. Numbers of pellets of different types from great skua Catharacta skua breeding territories at St Kilda (Outer Hebrides) and Foula, 1994 to 1996

\begin{tabular}{|c|c|c|c|c|c|c|c|c|c|c|c|}
\hline \multirow{3}{*}{$\begin{array}{l}\text { Pellet type } \\
\text { Bird }\end{array}$} & \multicolumn{6}{|c|}{ St Kilda } & \multicolumn{5}{|c|}{ Foula } \\
\hline & \multicolumn{2}{|c|}{1994} & \multicolumn{2}{|c|}{1995} & \multicolumn{2}{|c|}{1996} & \multicolumn{2}{|c|}{1994} & \multirow{2}{*}{$\begin{array}{c}1995 \\
\text { No }\end{array}$} & \multicolumn{2}{|c|}{1996} \\
\hline & 332 & $57.8 \%$ & 255 & $52.8 \%$ & 974 & $65.2 \%$ & 191 & $12.2 \%$ & & 9 & $4.6 \%$ \\
\hline Fish (excl. sandeel) & 136 & $23.7 \%$ & 127 & $26.3 \%$ & 242 & $16.2 \%$ & 1127 & $72.1 \%$ & data & 139 & $70.6 \%$ \\
\hline Sandeel & 2 & $0.3 \%$ & 1 & $0.2 \%$ & 0 & - & 92 & $5.9 \%$ & & 39 & $19.8 \%$ \\
\hline Goose barnacle ${ }^{\alpha}$ & 104 & $18.1 \%$ & 99 & $20.5 \%$ & 270 & $18.1 \%$ & 97 & $6.2 \%$ & & 3 & $1.5 \%$ \\
\hline Other Crustacean ${ }^{b}$ & 0 & - & 0 & - & 1 & $0.1 \%$ & 0 & - & & 0 & - \\
\hline Squid" & 0 & - & 1 & $0.2 \%$ & 2 & $0.1 \%$ & 0 & - & & 0 & - \\
\hline $\mathrm{Egg}^{\mathrm{d}}$ & 0 & - & 0 & - & 5 & $0.3 \%$ & 19 & $9.9 \%$ & & 0 & - \\
\hline Mammal & 0 & - & 0 & - & 0 & - & 37 & $2.4 \%$ & & 7 & $3.6 \%$ \\
\hline \multicolumn{12}{|c|}{${ }^{\circ}$ Lepas anatifera $(n=8)$} \\
\hline \multicolumn{12}{|c|}{ 'Brachyuran decapod } \\
\hline \multicolumn{12}{|c|}{5 Gonatus steenstrupi, 1 Rossia macrosoma and 6 unidentified juvenile Ommastrephidae } \\
\hline \multicolumn{12}{|c|}{$\begin{array}{l}\text { dSt Kilda: } 2 \text { fulmar, } 1 \text { great skua, } 1 \text { guillemot and } 1 \text { eider duck Somateria mollissima; Foula: } 15 \text { kittiwake (mostly from a single } \\
\text { egg specialist), } 1 \text { great skua, } 1 \text { eider duck and } 2 \text { unspecified auk (guillemot or razorbill) }\end{array}$} \\
\hline
\end{tabular}

between 13 and $34 \mathrm{~d}$, was then calculated as the deviation of actual from predicted weights at that age, according to the logistic equation relating weight to age (Hamer et al. 1991)

Great skuas regurgitate freshly obtained prey to their mate or chicks after returning from most absences from the territory (Furness 1987). Time spent away can therefore be used as an index of foraging effort (e.g Cairns 1987, Monaghan et al. 1989, Hamer et al. 1991, Phillips et al. 1996a). The mean number of adults present within their breeding territory was determined at 1 to $5 \mathrm{~d}$ intervals at both colonies in 1996. To control for diurnal variation in foraging effort, attendance was recorded between 09:00 and 13:00 h British Summer Time (BST). Visits to different areas of the 2 colonies were randomised to eliminate any bias caused by spatial variation in foraging patterns.

\section{RESULTS}

Diets

\section{Overall composition}

There was marked variation between sites in the proportion of pellets of different types (Tables 1 \& 2). At St Kilda, of the 4585 pellets recorded in 1994 to 1996, 55.8\% were bird, $0.1 \%$ were sandeel, $23.3 \%$ were other fish, and $20.2 \%$ were goose barnacle Lepas sp. This was very different from Foula where $11.5 \%$ of 2402 pellets were sandeel, $70.6 \%$ were other fish, only $10.0 \%$ were bird and $5.0 \%$ were goose barnacle. In logit loglinear analysis investigating the effects of year, breeding status and colony on the proportion of pellets in the 4 main prey categories, the fully saturated model

Table 2. Numbers of pellets of different types from great skua Catharacta skua club sites at St Kilda and Foula, 1994 to 1996

\begin{tabular}{|c|c|c|c|c|c|c|c|c|c|c|c|c|}
\hline \multirow{3}{*}{$\begin{array}{l}\text { Pellet type } \\
\text { Bird }\end{array}$} & \multicolumn{6}{|c|}{ St Kilda } & \multicolumn{6}{|c|}{ Foula } \\
\hline & \multicolumn{2}{|c|}{1994} & \multicolumn{2}{|c|}{1995} & \multicolumn{2}{|c|}{1996} & \multicolumn{2}{|c|}{1994} & \multicolumn{2}{|c|}{1995} & \multicolumn{2}{|c|}{1996} \\
\hline & 399 & $51.2 \%$ & 422 & $49.7 \%$ & 178 & $44.2 \%$ & 4 & $4.0 \%$ & 13 & $6.0 \%$ & 24 & $7.4 \%$ \\
\hline Fish (excl. sandeel) & 210 & $26.8 \%$ & 252 & $29.7 \%$ & 102 & $25.3 \%$ & 87 & $87.9 \%$ & 119 & $54.8 \%$ & 224 & $68.7 \%$ \\
\hline Sandeel & 2 & $0.3 \%$ & 0 & - & 0 & - & 4 & $4.0 \%$ & 78 & $35.9 \%$ & 64 & $19.6 \%$ \\
\hline Goose barnacle & 164 & $21.0 \%$ & 168 & $19.8 \%$ & 122 & $30.3 \%$ & 4 & $4.0 \%$ & 5 & $2.3 \%$ & 10 & $3.1 \%$ \\
\hline Other Crustacean ${ }^{\mathrm{a}}$ & 1 & $0.1 \%$ & 3 & $0.4 \%$ & 0 & - & 0 & - & 0 & - & 0 & - \\
\hline Squid $^{b}$ & 5 & $0.6 \%$ & 3 & $0.4 \%$ & 0 & - & 0 & - & 0 & - & 0 & - \\
\hline $\mathrm{Egg}^{c}$ & 1 & $0.1 \%$ & 0 & - & 1 & $0.2 \%$ & 0 & - & 1 & $0.5 \%$ & 1 & $0.3 \%$ \\
\hline Mammal & 0 & - & 1 & $0.1 \%$ & - & - & 0 & - & 1 & $0.5 \%$ & 3 & $0.9 \%$ \\
\hline
\end{tabular}


involving the fourth-order interaction between these variables was the only adequate fit for the data $(G=$ 4605, $\mathrm{df}=18, \mathrm{p}<0.0001$ ), with the full third-order model a very poor fit. Hence year, breeding status and colony all had significant and interactive effects on diet composition.

Annual variation in diet composition was, however, comparatively slight at St Kilda, the most apparent change being an increase in bird meat and a reduction in fish in breeders' diets, and a reduction in bird meat and an increase in goose barnacle in nonbreeders' diets in 1996. Annual variation was much more noticeable at Foula where the proportion of sandeel pellets varied between 6 and $20 \%$ in the diet of breeders, and between 4 and $36 \%$ in the diet of nonbreeders. A low occurrence of sandeel in some years was associated with an increase in predation on other seabirds by breeding adults, whereas nonbreeding birds responded mainly by increasing the proportion of other fish in the diet. Otherwise, the most conspicuous differences in pellet composition at breeding territories compared with club sites was a strong tendency for breeders to feed more on birds and less on fish, particularly at St Kilda.

\section{Bird species in the diet}

There was clearly a dramatic difference between the 2 colonies in the proporions of avian prey of different species (Tables $3 \& 4$ ). Overall, $43.5 \%$ of 2526 identifiable bird pellets from St Kilda were storm petrel (either Leach's petrel or British storm petrel), 25.3\% were black-legged kittiwake Rissa tridactyla or Larus spp. gull, $24.7 \%$ were auk (Alcidae) and $5.8 \%$ were northern fulmar Fulmarus glacialis. In marked contrast, $48.3 \%$ of the 178 bird pellets from Foula were auk, $23.3 \%$ were fulmar, $24.2 \%$ were kittiwake or other gull species and only $1.7 \%$ were storm petrel. The majority ( $83.9 \%, n=529$ pellets) of the storm petrel pellets from St Kilda identified to species were Leach's petrel. Of the 212 auk pellets from that colony identified to species, common guillemots Uria aalge (mostly chicks) were the commonest (64.6\%), followed by Atlantic puifins Fratercula arctica (34.4\%), with razorbills Alca torda very uncommon $(0.9 \%)$. The puffin remains were predominantly of adults, but included a few downy young. Probably only a very small proportion of gull pellets from either colony were Larus species, as

Table 3. Numbe:s of pellets containung identifiable bird remains from great skua Catharacta skua breeding territories at St Kilda and Foula, 1994 to 1996

\begin{tabular}{|c|c|c|c|c|c|c|c|c|}
\hline \multirow{2}{*}{$\begin{array}{l}\text { Pellet content } \\
\text { Storm petrel Cceanodroma leucorhoa or } \\
\text { Hydrobates pelagicus }\end{array}$} & \multicolumn{2}{|c|}{1994} & \multicolumn{2}{|c|}{$\begin{array}{c}\text { St Kilda } \\
1995\end{array}$} & \multicolumn{2}{|c|}{1996} & \multicolumn{2}{|c|}{$\begin{array}{c}\text { Foula } \\
1994\end{array}$} \\
\hline & 89 & $27.2 \%$ & 98 & $39.2 \%$ & 429 & $44.7 \%$ & 2 & $1.5 \%$ \\
\hline Kittiwake Rissa tridactyla or gull Larus spp. & 170 & $51.2 \%$ & 99 & $38.6 \%$ & 41 & $4.3 \%$ & 30 & $21.9 \%$ \\
\hline Auk & 45 & $13.8 \%$ & 52 & $20.8 \%$ & 394 & $41.0 \%$ & 62 & $45.3 \%$ \\
\hline Fulmar Fulmarus glacialis & 20 & $6.1 \%$ & 1 & $0.4 \%$ & 84 & $8.8 \%$ & 40 & $29.2 \%$ \\
\hline Manx shearwater Puffinus puffinus & 1 & $0.3 \%$ & 0 & - & 8 & $0.8 \%$ & 0 & - \\
\hline Other identified bird ${ }^{a}$ & 0 & - & 0 & - & 4 & $0.4 \%$ & 3 & $2.2 \%$ \\
\hline \multicolumn{9}{|c|}{$\begin{array}{l}\text { aSt Kilda: eider duck Somateria mollissima, starling Sturnus vulgaris, snipe Gallinago gallinago and an unidentified tern } \\
\text { adult; Foula: } 2 \text { shag Phalacrocorax aristotelis and } 1 \text { Arctic tern Sterna paradisaea. In addition to these species, carcasses of a } \\
\text { male golden oriole Onlolus oriolus, a female tufted duck. Aythya fuligula, } 2 \text { oystercatchers Haematopus ostralegus, and } \\
2 \text { lesser black-backed gull chicks Larus fuscus were recorded on breeding territories at St Kilda }\end{array}$} \\
\hline
\end{tabular}

Table 4. Numbers of pellets containing identifiable bird remains from great skua Catharacta skua club sites at St Kilda and Fould, 1994 to 1996

\begin{tabular}{|c|c|c|c|c|c|c|c|c|}
\hline \multirow{2}{*}{$\begin{array}{l}\text { Pellet content } \\
\text { Storm petrel Oceanodroma leucorhoa or } \\
\text { Hydrobates pelagicus }\end{array}$} & \multicolumn{2}{|c|}{1994} & \multicolumn{2}{|c|}{$\begin{array}{c}\text { St Kilda } \\
1995\end{array}$} & \multicolumn{2}{|c|}{1996} & \multicolumn{2}{|c|}{$\begin{array}{c}\text { Foula } \\
1994-1996 \text { (pooled) }\end{array}$} \\
\hline & 170 & $42.6 \%$ & 191 & $46.4 \%$ & 123 & $69.1 \%$ & 1 & $2.4 \%$ \\
\hline Kittiwake Rissa tridactyla or gull Larus spp. & 189 & $47.4 \%$ & 135 & $32.8 \%$ & 3 & $1.7 \%$ & 13 & $31.7 \%$ \\
\hline Auk & 30 & $7.5 \%$ & 75 & $18.2 \%$ & 28 & $: 5.7 \%$ & 24 & $58.5 \%$ \\
\hline Fulmar Fulmarus glacialis & 9 & $2.3 \%$ & 11 & $2.7 \%$ & 22 & $2.4 \%$ & 1 & $2.4 \%$ \\
\hline Manx shearwater Puffinus puffinus & 1 & $0.3 \%$ & 0 & - & 2 & $1.1 \%$ & 0 & - \\
\hline Other adentified bird ${ }^{d}$ & 0 & - & 0 & - & 0 & - & 2 & $4.9 \%$ \\
\hline
\end{tabular}


Table 5. Numbers of great skua Catharacta skua chick regurgitates of different types at St Kilda and Foula

\begin{tabular}{|c|c|c|c|c|c|c|c|c|}
\hline \multirow{2}{*}{$\begin{array}{l}\text { Type } \\
\text { Bird flesh }\end{array}$} & \multicolumn{2}{|c|}{$\begin{array}{c}\text { St Kilda } \\
1996\end{array}$} & & 994 & & 995 & & 996 \\
\hline & 9 & $47.4 \%$ & 5 & $8.6 \%$ & 0 & .- & 1 & $1.6 \%$ \\
\hline Gadid fish & 10 & $52.6 \%$ & 31 & $53.5 \%$ & 5 & $29.4 \%$ & 21 & $33.9 \%$ \\
\hline Sandeel & 0 & - & 15 & $25.9 \%$ & 10 & $58.8 \%$ & 37 & $59.7 \%$ \\
\hline Herring & 0 & - & 6 & $10.3 \%$ & 1 & $5.9 \%$ & 1 & $1.6 \%$ \\
\hline Unidentified fish & 0 & - & 0 & - & 0 & - & 1 & $1.6 \%$ \\
\hline Fish offal & 0 & - & 0 & - & 1 & $5.9 \%$ & 0 & - \\
\hline Squid & 0 & - & 1 & $1.7 \%$ & 0 & - & 1 & $1.6 \%$ \\
\hline
\end{tabular}

many pellets contained kittiwake skulls, and in addition the population sizes of other gulls at both colonies are comparatively small (Furness 1983a, Tasker et al. 1988)

In logit loglinear analysis investigating the effects of year, breeding status and colony on the proportion of pellets in the 4 main species categories (storm petrel, kittiwake/gull, auk or fulmar), only the fully saturated model involving the fourth-order interaction between these variables was an adequate fit for the data $(G=$ 878, df $=9, p<0.0001)$. Year, breeding status and colony all therefore had significant and interactive effects on avian prey composition. For the purposes of analysis, the pooled data set from club sites on Foula was included as if it had been collected in 1996, since the majority of pellets were collected in that year There was considerable annual variation in species composition at St Kilda, with notable increases in petrel and auk pellets, and a decline in kittiwake pellets collected at both breeding territories and the club site over the 3 yr. Avian prey composition also depended on breeding status. In all 3 years at St Kilda there were fewer petrel but more auk and more kittiwake pellets recorded at breeding territories than at the club site. In addition in 1995 and 1996, fewer fulmar pellets were recorded at breeding territories. By contrast, on Foula kittiwake and auk pellets were less frequent, and fulmar pellets more frequent, at breeding territories compared with club sites.

\section{Chick diet}

No chicks regurgitated goose barnacles. Comparing the proportion of regurgitates in the 3 main prey categories (bird, sandeel or other fish, including herring and offal) there was significant annual variation at Foula (Table 5; $\chi^{2}=17.7, \mathrm{df}=4, \mathrm{p}<0.01$ ) and a significant difference between Foula and St Kilda in $1996\left(\chi^{2}=36.4\right.$, df $\left.=2, p<0.0001\right)$. Bird flesh was recorded much more frequently in chick regurgitates at St Kilda $(47.4 \%)$ compared with Foula $(4.4 \%)$. In addition, 26 to $60 \%$ of samples on Foula were of sandeel, yet this item was unrecorded in chick diet at St Kilda.

\section{Productivity, chick growth and adult foraging effort}

Summary statistics for great skuas breeding at St Kilda and Foula are shown in Table 6. There were significant differences among years and between colonies

Table 6. Breeding statistics (mean \pm SE) for great skuas Catharacta skua at Foula and St Kilda, 1994 to 1996. Sample size shown in parentheses. Differences non-significant unless indicated otherwise. ${ }^{\prime} p<0.01, \cdots p<0.001, \cdots p<0.0001$

\begin{tabular}{|c|c|c|c|c|c|c|c|}
\hline Year & Colony & $\begin{array}{c}\text { Mean egg } \\
\text { length (mm) }\end{array}$ & $\begin{array}{c}\text { Mean egg } \\
\text { breadth (mm) }\end{array}$ & $\begin{array}{c}\text { Mean egg } \\
\text { volume }(\mathrm{ml})\end{array}$ & $\begin{array}{l}\text { Mean clutch } \\
\text { volume }(\mathrm{ml})\end{array}$ & $\begin{array}{l}\text { Chicks hatched } \\
\text { per pair }\end{array}$ & $\begin{array}{l}\text { Chicks fledged } \\
\text { per pair }\end{array}$ \\
\hline 1994 & Foula & $70.7 \pm 0.1(318)$ & $49.7 \pm 0.1(318)$ & $83.9 \pm 0.3(318)$ & $168.0 \pm 0.8(158)$ & $1.59(164)$ & $0.86(142)$ \\
\hline 1995 & Foula & $70.7 \pm 0.2(392)$ & $49.6 \pm 0.1(391)$ & $83.6 \pm 0.3(391)$ & $167.1 \pm 0.7(195)$ & $1.60(198)$ & $1.13(178)$ \\
\hline 1996 & Foula & $70.5 \pm 0.1(432)$ & $49.3 \pm 0.1(429)$ & $82.3 \pm 0.3(429)$ & $164.6 \pm 0.7(213)$ & - & $1.49^{(63)^{\prime}}$ \\
\hline 1996 & St Kilda & $70.5 \pm 0.1(343)$ & $49.8 \pm 0.1(343)$ & $84.4 \pm 0.4(343)$ & $169.4 \pm 1.0(153)$ & $1.29(195)$ & $0.96(184)$ \\
\hline \multicolumn{2}{|c|}{ Colony effect } & $F_{1,773}=2.8$ & $F_{1,770}=23.3 \cdots$ & $F_{1,770}=20.6 \cdots$ & $F_{1,366}=15.2 \cdots$ & $\begin{array}{c}\chi^{2}=25.0^{\cdots} \cdot \cdot \\
\mathrm{df}=2^{b}\end{array}$ & $\begin{array}{l}\chi^{2}=0.4 \\
\mathrm{df}=2^{b}\end{array}$ \\
\hline \multicolumn{2}{|c|}{ Year effect (on Foula) } & ) $F_{2,1139}=0.5$ & $F_{2,1135}=13.1 \cdots$ & $F_{21135}=9.1 \cdots$ & $F_{2,563}=5.7 \cdot$ & $\begin{array}{c}\chi^{2}=0.2 \\
\mathrm{df}=2\end{array}$ & $\begin{array}{c}\chi^{2}=11.2 \cdot \\
\mathrm{df}=2\end{array}$ \\
\hline
\end{tabular}




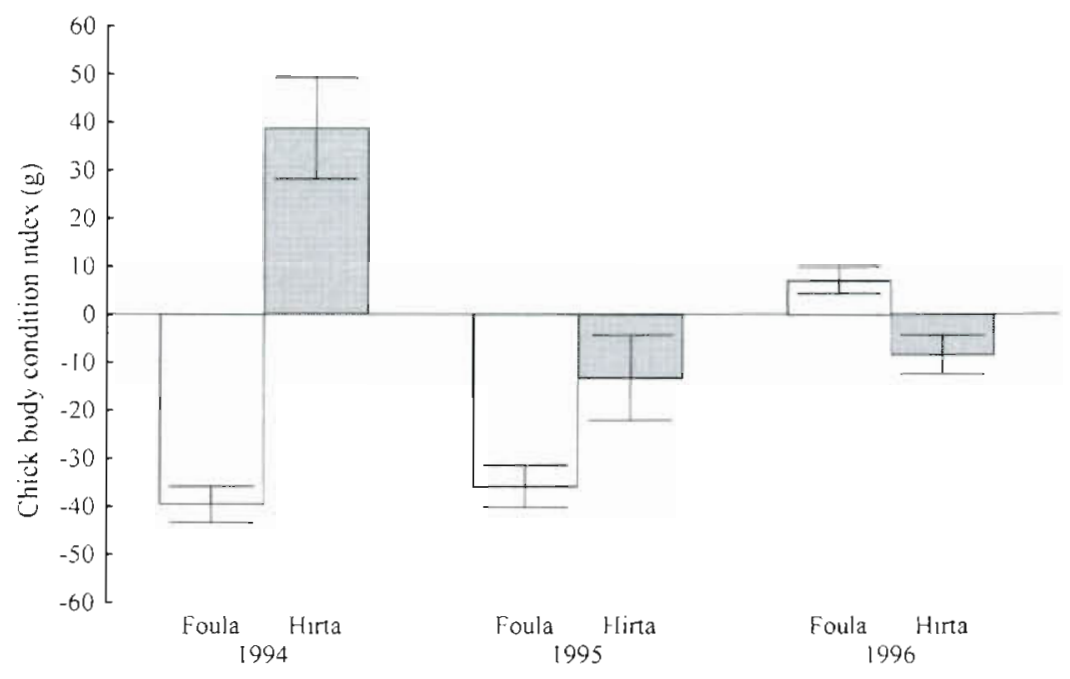

Fig. 1 Catharacta skua. Mean body condition indices (mean \pm SE) of great skua chicks at Foula and St Kilda, 1994 to 1996

\section{DISCUSSION}

The diets of great skuas breeding at these 2 colonies were quite distinct (Tables 1 \& 2). Adults at St Kilda fed to a large extent upon other seabirds, and to a lesser degree on fish or goose barnacles. In contrast, avian predation was comparatively rare on Foula and the large majority of pellets were of sandeel or gadid fish. This was also the case during the late 1970 s and early 1980 s at that colony (Furness \& Hislop 1981, Hamer et al. 1991). The low occurrence of sandeels in the diet at St Kilda reflects a low abundance in waters adjacent to the colony (Leaper et al. 1988). Other seabirds (notably guillemots, puffins and gannets Morus bassanus) breeding at St Kilda are known to feed on sandeels, obtained in mean egg breadth, egg volume and clutch volume (2-egg clutches only), but not egg length. Schefferanges tests indicated that egg dimensions were significantly smaller on Foula in 1996 than in 1995 or 1994 with no difference between the latter 2 years. The magnitude of the differences among years on Foula was clearly very slight (less than $1 \%$ ), but more notable differences existed (up to $3 \%$ ) between Foula and St Kilda in 1996.

The number of chicks hatched per pair was significantly greater on Foula in 1994 and 1995 than at St Kilda in 1996. However, despite this, there was no significant difference between the number of chicks fledged per pair at St Kilda compared with Foula in any year. Fledging success on Foula showed annual variation, with productivity greater in 1995 than in 1994. There was significant annual and inter-colony variation in chick body condition, with chicks having the highest body condition at St Kilda in 1994, and the poorest body condition on Foula in 1994 and 1995 (Fig. 1; 2-way ANOVA, colony effect $F_{1.1309}=5.5, \mathrm{p}<$ 0.02 , year effect $\left.F_{2,1309}=28.1, p<0.001\right)$. However, there was a significant interaction $\left(F_{2,1309}=25.5, \mathrm{p}<0.001\right)$ indicating that the difference between colonies was not consistent across years.

Seasonal changes in adult territorial attendance are illustrated in Fig. 2. Mean territorial attendance at each stage of the season was much higher at St Kilda than on Foula in 1996 (paired sample t-test $t_{24}=16.1, \mathrm{p}<0.0011$. $40 \mathrm{~km}$ to the east (Harris 1984. Harris \& Wanless 1985. Leaper et al. 1988). The paucity of sandeel in the diet of great skuas strongly suggests that given alternative prey (seabirds) available closer to the colony, travelling this distance is not an efficient foraging strategy for great skuas.

Most of the fish recorded in the diet at both colonies (excluding sandeel) were mid-water or bottomdwelling species, and therefore made available to skuas only through discarding by commercial fishing vessels (Furness \& Hislop 1981, Hamer et al. 1991. Phillips et al. 1997). Great skuas may obtain these discards either directly by scavenging behind trawlers or indirectly by kleptoparasitism. At St Kilda in particular, predominantly at an offshore bank approximately

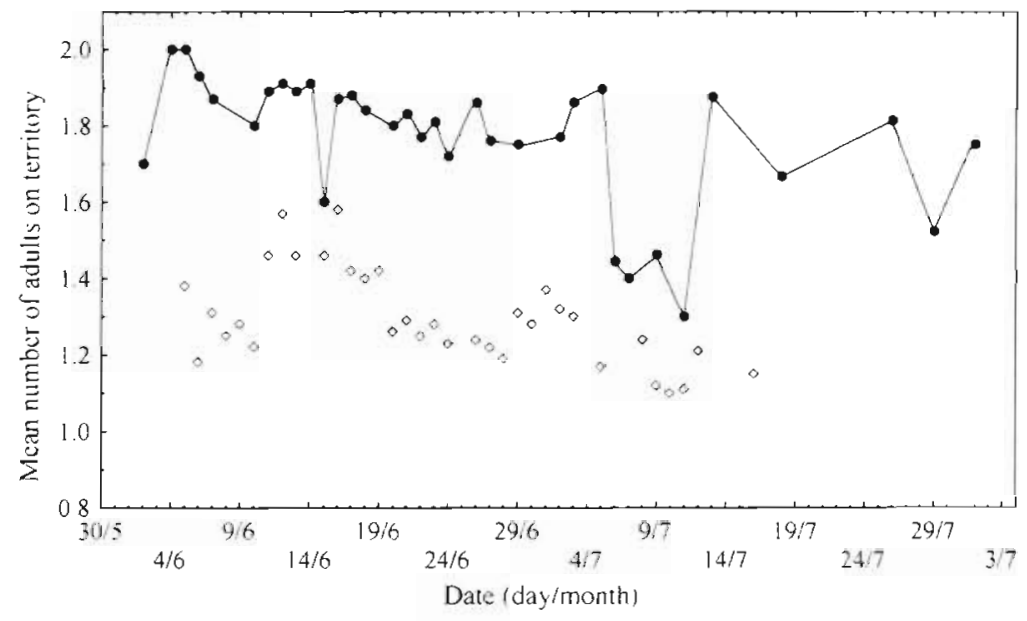

Fig. 2 Seasonal changes in attendance (for 09:00 to 13:00 h BST) of great skua Catharacta skua adults at Foula ( ० ) and St Kilda $(\rightarrow-)$ in 1996 
large numbers of skuas pursue gannets in the vicinity of the large colony on Boreray and its 2 adjacent stacks (R.A.P. pers. obs., S. Murray pers. comm.).

The potential volume of discards from fisheries in the waters around St Kilda is considerably less than that available around Foula. Landings of demersal fish species in Scottish ports from the sea area within the fisheries square (approximately $48 \times 48 \mathrm{~km}$ ) immediately surrounding Foula were $4120 \mathrm{t}$ and $4060 \mathrm{t}$ in 1994 and 1995, respectively, compared with $410 \mathrm{t}$ and $400 \mathrm{t}$ from the St Kilda square in these 2 yr (A. Newton pers. comm.). The totals if the adjacent 8 fisheries squares are included (i.e. approximately a $145 \times 145 \mathrm{~km}$ sea area) were $29620 \mathrm{t}$ and $21880 \mathrm{t}$ for Foula, and $2630 \mathrm{t}$ and $3340 \mathrm{t}$ for St Kilda in 1994 and 1995. Although it is difficult to estimate the discard component represented by this catch, it is reasonable to assume that total discard volume from vessels operating around Foula is at least an order of magnitude higher than that available around St Kilda

Great skuas fed on goose barnacles to a much greater extent at St Kilda ( $>20 \%$ of pellets) than at Foula ( $5 \%$ of pellets) or at the colony on Handa, Sutherland (Scotland) ( $<2 \%$; Baber 1992). Tristan skuas Catharacta antarctica hamiltoni at Inaccessible Island (Tristan de Cunha) also consume goose barnacles, but again in low numbers ( $<3 \%$ of pellets), and these skuas left large quantities to rot even though they were readily accessible (Fraser 1984, Ryan \& Moloney 1991). The reproductive performance of glaucous gulls Larus glaucescens was lower when adults ate more mussels and fewer fish (Murphy et al. 1984). Goose barnacles or other marine invertebrates would therefore appear not to be preferred food items, presumably because of their low nutritive value (Massias \& Becker 1990). The relatively high incidence of goose barnacles, which are essentially pelagic, in the diet of skuas at St Kilda but not Foula probably reflects the former's oceanic location, far to the west of the Outer Hebrides.

In addition to differences between the 2 sites, dietary composition at both colonies showed some effects of year and of breeding status, although this variation was comparatively minor. Most notably, the importance of sandeels in the diet differed among years on Foula, presumably as a reflection of changes in availability in the surrounding waters. In addition, in all years, breeding great skuas tended to feed more on birds and less on fish than did nonbreeders. Similar annual variation in diet and dietary segregation between birds of different breeding status is also recorded at other skua colonies and for other seabirds (Bayes et al. 1964, Furness \& Hislop 1981, Zipan \& Norman 1993, Phillips et al. 1996b).

There were clearly considerable differences between the 2 colonies, between birds of different breed- ing status, and among years in the relative importance of different bird species in the diet (Tables $3 \& 4$ ). Some of the variation between colonies can be explained by differences in prey population sizes. Currently, Leach's storm petrels breed in very low numbers, if at all, on Foula, which explains their absence from the diet at that colony (Lloyd et al. 1991). Annual variation in prey species at a colony could be a consequence of differences in the breeding success or the timing of breeding by prey species (see e.g. Fraser 1984, Watanuki 1989, Ryan \& Moloney 1991). In addition, skuas frequently show a considerable degree of dietary specialisation (Bayes et al. 1964, Green 1986, Ryan \& Moloney 1991, Zipan \& Norman 1993) which might also be a factor, especially if different individuals were sampled at each colony in different years.

The large number of storm petrels, the majority of which were Leach's petrel, taken by great skuas at St Kilda was unexpected, in spite of the large populations of both Leach's and British storm petrels at that site. It is unclear how great skuas are able to catch these far smaller and presumably more manoeuvrable, albeit slow-flying species (see Alerstam et al. 1993 for details of Wilson's storm petrel Oceanites oceanicus flight speed). Storm petrels have been recorded at high frequencies in the diet of skuas at other locations (Fraser 1984, Green 1986, Young et al. 1988, Norman \& Ward 1990, Ryan \& Moloney 1991, Zipan \& Norman 1993). As neither British storm petrels nor Leach's petrels are recorded outside their burrows on land during daylight hours, it might be assumed that great skuas at St Kilda are able to catch them at sea. However, Leaper et al. (1988) found that storm petrels were uncommon in transects within $25 \mathrm{~km}$ of St Kilda, although they were found at much greater densities $50 \mathrm{~km}$ away, at the shelf edge to the west. Brown skuas at the Chathams (New Zealand) and Tristan skuas at Gough and Inaccessible Islands hunt almost exclusively at night, catching petrels on the ground or in some cases excavating burrows (Furness 1987, Young et al. 1988, Ryan \& Moloney 1991), and herring gulls Larus argentatus in Newfoundland and slaty-backed gulls L. schistisagus in Japan catch Leach's petrels during the latter's nocturnal visits to the colony (Watanuki 1986, Pierotti \& Annett 1991). Some great skuas at St Kilda might have the same feeding habits, although great skuas at other north Atlantic colonies appear to be largely inactive at night (Bayes et al. 1964, Furness 1987, Klomp \& Furness 1992).

A high availability of sandeels and discarded whitefish were considered responsible for the rapid growth and good breeding success of great skuas in Shetland for much of the current century (Furness \& Hislop 1981). This appeared to be confirmed by poor chick growth, low annual productivity and reduced adult 
survivorship during the late 1980 s as a consequence of drastically reduced sandeel availability, despite the incorporation of increasing quantities of bird meat in the diet (Hamer et al. 1991). On the basis of these results, it might be concluded that bird flesh is in some way sub-optimal as a source of nutrition, but this is not necessarily the case. Skuas at most sub-Antarctic sites rely predominantly on predation on penguins or burrowing petrels (Schramm 1983, Fraser 1984, Green 1986, Furness 1987, Ryan \& Moloney 1991, Zipan \& Norman 1993, Mund \& Miller 1995). In addition, a recent study found that the chicks of male slatybacked gulls that specialised in predation on seabirds had higher growth rates and were more likely to fledge (Watanuki 1992). Similarly, herring gull pairs that consumed more gull chicks and fish, and fewer marine invertebrates, were more likely to fledge their chicks successfully and within the successful group, the chicks of specialist cannibals grew at a significantly faster rate (Bukacinska et al. 1996). In these cases, predation on other seabirds is clearly a very successful foraging strategy.

The population of great skuas on Hirta has increased rapidly in recent years, at a rate too high to be accounted for solely by philopatric recruitment (Phillips et al. 1997). Approximately $66 \%$ of recruits in 1995 and 1996 were estimated to have fledged from populations elsewhere, and were presumably attracted to Hirta at least in part because of abundant local food supplies. Egg and clutch volumes were slightly lower at Foula than at St Kilda, suggesting (on the assumption that the difference is of some biological significance and not an artefact of minor variation in measuring technique) a greater quantity or higher quality of food available to females during egg formation (Bolton et al. 1992). Incubating adults were in comparable body condition at St Kilda and on Foula (authors' unpubl. data). Chick body condition was also better in some years and foraging effort was much lower at Hirta than at Foula suggesting a greater availability of food during the nestling period at St Kilda. The difference was not so large as to affect overall breeding success, but productivity at both sites was above average compared with other monitored colonies in Shetland and Orkney (Walsh et al. 1995. Thompson et al. 1996), though less than recorded at Foula during the 1970s (Furness 1984). There is therefore no obvious disadvantage for great skuas in the consumption of bird flesh per se. The best explanation for the decline in reproductive performance at Foula associated with poor sandeel availability during the late 1980 s is that at that colony it was uneconomical in terms of adult time or energy budgets to feed by predation on seabirds. Why this should be the case when there were potentially huge numbers of seabird prey available at Foula is unclear, but may be related to a high level of intra-specific competition. Klomp \& Furness (1992) estimated that 2300 to 2400 pairs of great skuas were breeding on Foula in 1988 to 1990. By comparison at St Kilda, where the total number of great skuas is an order of magnitude lower, predation on other seabirds would appear to be a very effective feeding method for adults to adopt.

Acknowledgements. Fieldwork in 1996 on Hirta was supported by a grant from Scottish Natural Heritage. For help with logistıcs at St Kilda we thank John Love, Stuart Murray, Gail Churchill, Movement Control (Benbecula) and the Captain and crew of HMAV 'Arakan' Fieldwork on Foula was supported by a grants from the Junta Nacional de Investigaçāo Cientifica e Tecnológica (Programa Praxis XXI) to P.C. and from the Shetland Oil Terminal Environmental Advisory Group. Many thanks are due to Werner Schwarzhans for help in identifying fish otoliths, to Bernie Zonfrillo and Mike Imber for help in identifying squid beaks from Hirta and to Martin Attrill for crustacean identifications. Andrew Newton from the Dept of Agriculture and Fisheries for Scotland Marine Lab., Aberdeen kindly provided access to unpublished fisheries data. We thank Jim Vaughan and Paul Tyler for help with collecting skua pellets in 1994 and 1995 and Stuart Bearhop for help with fieldwork on Foula in 1996.

\section{LITERATURE CITED}

Alerstam T, Gudmundsson GA, Larsson B (1993) Flight tracks and speeds of Antarctic and Atlantic seabirds: radar and optical measurments. Phil Trans R Soc Lond B 340:55-67

Baber IA (1992) Breeding ecology of some seabirds on Handa Island, Sutherland, with particular reference to the use of seabirds as indicators of food availability. MSc thesis, University of Glasgow

Bayes JC, Dawson MJ, Potts GR (1964) The food and feeding behaviour of the great skua in the Faroes. Bird Study 11. 272-279

Bolton M, Houston D, Monaghan P (1992) Nutritional. constraints on egg formation in the lesser black-backed gull: an experimental study. J Anim Ecol 61:521-532

Bukacinska M, Bukacinski D, Spaans AL (1996) Attendance and diet in relation to breeding success in herring gulls (Larus argentatus). Auk 113:300-309

Cairns DK (1987) Seabirds as indicators of marine food supplies. Biol Ocean 5:261-271

Clarke MR (1986) A handbook for the identification of cephalopod beaks. Clarendon Press, Oxford

Fraser MW (1984) Foods of subantarctic skuas on Inaccessible Island. Ostrich 55:192-195

Furness RW (1983a) The birds of Foula. Brathay Hall Trust, Ambleside

Furness RW (1983b) Variations in size and growth of great skua Catharacta skua chicks in relation to adult age, hatching date, egg volume, brood size and hatching sequence. J Zool (Lond) 199:101-116

Furness RW (1984) Influences of adult age and experience, nest location, clutch size and laying sequence on the breeding success of the great skua Catharacta skua. J Zool (Lond) 202:565-576

Furness RW (1987) The skuas. T \& AD Poyser, Calton

Furness RW, Hislop JRG (1981) Diets and feeding ecology of great skuas Catharacta skua during the breeding season. J Zool (Lond) 195:1-23 
Green K (1986) Observations on the food of the south polar skua, Catharacta maccormicki near Davis, Antarctica. Polar Biol 6:185-186

Hamer KC, Furness RW, Caldow RWG (1991) The effects of changes in food availability on the breeding ecology of great skuas Catharacta skua in Shetland. J Zool (Lond) 223:175-188

Härkönen T (1986) Guide to the otoliths of the bony fishes of the northeast Atlantic. Danbiv ApS, Hellerup, Denmark

Harris MP (1984) The puffin. T \& AD Poyser, Calton

Harris MP, Wanless S (1985) Fish fed to young gullemots Uria alge, and used in display on the Isle of May, Scotland. J Zool (Lond) 207:441-458

Klomp NI, Furness RW (1991) Recruitment in long-lived birds studies of nonbreeding great skuas. Proc Int Ornithological Congr XX:1678-1688

Klomp NI, Furness RW (1992) Nonbreeders as a buffer against environmental stress: declines in numbers of great skuas on Foula, Shetland, and prediction of future recruitment. J Appl Ecol 29:341-348

Leaper GM, Webb A, Benn S, Prendergast HDV, Tasker ML Schofield R (1988) Seabird studies around St Kilda, June 1987 Nature Conservancy Council CSD Report 804 Aberdeen

Lloyd CS, Tasker ML, Partridge K (1991) The status of seabirds in Britain and lreland. T \& AD Poyser, Calton

Love JA. (1976) ldentification from measurements of small petrel remains in gull and skua pellets. Bird Study 23:162

Massias A, Becker PH (1990) Nutritive value of food and growth in common tern Sterna hirundo. Ornis Scand 21. $187-194$

Meek ER, Sim IMW, Ribbands B (1994) Breeding skuas in Orkney: the results of the 1992 census. Seabird 16: $34-40$

Monaghan P, Uttley JD, Burns MD, Thaine C, Blackwood J (1989) The relationship between food supply, reproductive effort and breeding success in Arctic terns Sterna paradisaea. J Anim Ecol 58:261-274

Mund MJ, Miller GD (1995) Diet of the south polar skua Catharacta maccormicki at Cape Bird, Ross Island Antarctica. Polar Biol 15:453-455

Murphy EC, Day R.H, Oakley KL, Hoover AA (1984) Dietary changes and poor reproductive performance in glaucouswinged gulls. Auk 101:532-541

Norman FI, Ward SJ (1990) Foods of the south polar skua at Hop Island, Rauer Group, East Antarctica. Polar Biol 10 $489-493$

Norusis MJ (1988) Advanced Statistics SPSS/PC+. SPSS Inc Chicago

Phillips RA, Caldow RWG, Furness RW (1996a) The influence of food availability on the breeding effort and reproduc-

This article was submitted to the editor tive success of Arctic skuas Stercorarius parasiticus. Ibis 138:410-419

Phillips RA, Ratcliffe N, Riley HT (1996b) Factors influencing the foraging range and marine distribution of UK seabirds with an evaluation of possible marine extensions to Special Protection Areas in Scotland. Scottish Natural Heritage Research and Advisory Report, Edinburgh

Phillips RA, Thompson DR, Hamer KC (1997) The population and feeding ecology of great skuas Catharacta skua at Hirta, St Kilda. Report to Scottish Natural Heritage, Inverness

Pierotti R, Annett CA (1991) Diet choice in the herring gull: constraints imposed by reproductive and ecological factors. Ecology 72:319-328

Rennie FW (1988) The status and distribution of the great skua in the Western 1sles. Scott Birds 15:80-82

Ryan PG. Moloney CL (1991) Prey selection and temporal variation in the diet of subantarctic skuas at Inaccessible Island, Tristan da Cunha. Ostrich 62:52-58

Schramm M (1983) Predation by subantarctic skuas Catharacta antarctica on burrowing petrels at Marion Island. S Afr J Antarct Res 13:41-44

Sears J, Ellis PM. Suddaby D. Harrop HR (1995) The status of breeding Arctic skuas Stercorarius parasiticus and great skuas Catharacta skua in Shetland in 1992. Seabird 17. $21-31$

Tasker ML, Moore PR, Schofield RA (1988) The seabirds of St Kilda, 1987. Scott Birds 15:21-29

Thompson KR, Brindley E, Heubeck M (1996) Seabird numbers and breeding success in Britain and Ireland, 1995. Joint Nature Conservation Committee Report 20, Peterborough

Walsh PM, Brindley E, Heubeck M (1995) Seabird numbers and breeding success in Britain and lreland, 1994. Joint Nature Conservation Committee Report 18, Peterborough

Watanuki Y (1986) Moonlight avoidance behaviour in Leach's storm-petrels as a defence against slaty-backed gulls. Auk 103:14-22

Watanuki Y (1989) Sex and individual variations in the diet of slaty-backed gulls breeding on Teuri Island, Hokkaido. Jap J Ornithol 38:1-13

Watanuki Y (1992) Individual diet difference, parental care and reproductive success in slaty-backed gulls. Condor 94:159-171

Young EC, Jenkins PE, Douglas ME, Lovegrove TG (1988) Nocturnal foraging by Chatham lsland skuas. NZ J Ecol 11:113-117

Zipan W, Norman Fl (1993) Foods of the south polar skua Catharacta maccormacki in the eastern Larsemann Hills, Princess Elizabeth Land, East Antarctica. Polar Biol 13: $255-262$

Manuscript first received: February 17, 1997

Revised version accepted: April 23, 1997 